ISSN:2656-4270 (Online) 1410-4466 (Print) Accredited by Ministry of Research, Technology, and Higher Education with the ranking of Sinta (S4) SK NO.28/E/KPT/2019, 26th September 2019
Buletin Penelitian Sosial Ekonomi Pertanian Fakultas Pertanian Universitas Haluoleo

2021:23(1):27-36

http://ojs.uho.ac.id/index.php/sosek

doi: http://dx.doi.org/10.37149/sosek.v23i1.16762

\title{
FORECASTING THE PRICE OF CAYENNE PEPPER IN THE SURABAYA CITY
}

\author{
Joshua Eka Putra ${ }^{\left.{ }^{*}\right)}$, Hani Perwitasari ${ }^{11}$, Jamhari ${ }^{1{ }^{1}}$ \\ ${ }^{1}$ Department of Agricultural Socio-Economics, Faculty of Agriculture, Gadjah Mada University
}

${ }^{*}$ Corresponding author: joshua.e@mail.ugm.ac.id

To cite this article:

Putra, J., Perwitasari, H., \& Jamhari, J. (2021). Forecasting the Price of Cayenne Pepper in the Surabaya City. Buletin Penelitian Sosial Ekonomi Pertanian Fakultas Pertanian Universitas Haluoleo, 23(1), 27 - 36. doi:http://dx.doi.org/10.37149/bpsosek.v23i1.16762

Received: February 23, 2021; Accepted: April 29, 2021; Published: April 30, 2021

\begin{abstract}
The price fluctuation of cayenne pepper in Indonesia is relatively high. Price fluctuations have an impact on consumers significantly when prices increase. This causes consumers to find it challenging to fulfil their daily needs for chilli. The effects of price fluctuations for farmers, namely: farmers have difficulty making production decisions. This causes the risk of cayenne pepper farming to become high. Predicting the price of cayenne pepper in the future is an effort to minimize the risk of cayenne pepper farming and industries requiring cayenne pepper. This study aims (1) to determine the forecasting model for cayenne pepper prices in Surabaya City (2) to predict the price of cayenne pepper during the period January 2020 - June 2020 in the Surabaya City using the ARIMA method. The analyzed data is cayenne pepper prices from July 2010 to December 2019 sourced from the Badan Pusat Statistik (BPS). The analysis results show that the best ARIMA model in estimating the price of red chilli in Surabaya is ARIMA $(1,0,1)$, with a MAPE of $3.84 \%$. The forecast results for the price of cayenne pepper in Surabaya are proven and have decreased.
\end{abstract}

Keywords: ARIMA; cayenne pepper; forecasting; price

\section{INTRODUCTION}

Cayenne pepper has an essential role in household consumption, but the off-farm aspect of this commodity often experiences problems. One of the problems in the off-farm part of red cayenne pepper is high price fluctuations throughout the year. Price fluctuations in cayenne pepper often cause this commodity to become one of the causes of inflation. The Central Statistics Agency (BPS) noted that cayenne pepper in 2019 contributed to the inflation of $0.05 \%$. The existence of price fluctuations impacts farmers in making production decisions and creates disincentives in running farming. Price fluctuations also affect consumers, especially when there is an increase in purchase prices which causes consumers to have difficulty meeting their daily needs. Farmers need price certainty to reduce the risk of loss due to falling product prices. Consumers also need to know costs to control spending. Therefore, producers and consumers need to understand the pattern of price data to reduce the risk of losses due to price uncertainty. The same thing as previous research (Pratiwi, Rosyid, \& Hasyim, 2020) stated that chilli prices have unstable and fluctuating characteristics. This causes stakeholders to find it challenging to make decisions about chilli prices. The study was conducted using time series data on the costs of large red chillies and curly red chillies for 40 periods from July 2016 to October 2019 to predict the prices of red chillies and curly red chillies for the following 12 periods starting in November 2019 and ending in October. 2020. The data is obtained from the Food Price application (Strategic Food Price Information Center) of Bank Indonesia using the price of cayenne pepper in the Special Region of Yogyakarta. The results of the forecasting model using ARIMA show that the costs of large red chillies and curly red chillies for 12 periods have increased gradually, and the forecasting results are close to the actual data.

A study conducted by Perihartini et al.(2018) stated that the increase in chilli prices in certain seasons significantly affects the inflation rate. Generally, the cost of red chilli will decrease along with the passing of certain big days. Since 2014 the price of large curly red chillies has continued to fluctuate until the beginning of 2017. This is indeed troubling to the community, considering that the 
community's dependence on large curly red chillies is still relatively high. Therefore, an analysis is used to predict the purchase price of chilli to anticipate an increase in the price of chilli in the future. The analysis results were carried out using the ARIMA Box-Jenkins method, forecasting the cost of big red curly chillies in Banyumas Regency decreased from March to December 2017.

The research entitled Forecasting the price and production of cayenne pepper in East Java Province conducted by Nabilah (2017) stated that the high cost of chilli production at the farmer level was one of the factors causing the increase in chilli prices in East Java in 2015. This study carried out forecasting in price and quantity of cayenne pepper production in East Java Province using the ARIMA Box-Jenkins method. The results showed that the best model for predicting price data is ARIMA $(0,0,1)$ with an RMSE value of 14103,53 . The model for forecasting production data is ARIMA $(0,0,1)$ with an RMSE value of 41842.20 . The forecast results show that the development of the price of cayenne pepper in East Java Province in 2017 has decreased. This is also influenced by the amount of production that has increased.

One way to avoid the risk of price fluctuations is to know the pattern of price fluctuations. Patterns of price fluctuations can be used as a factor to predict future prices. Price forecasting can be taken into consideration by farmers to start the planting period of a commodity to get maximum income at harvest. Price forecasting is also beneficial for the government because it can be considered in policymaking. Traders and consumers can benefit from this price forecasting because they can predict future prices (Prakoso, 2018).

East Java Province is the largest centre of cayenne pepper producer in Indonesia, with an average production contribution from 2014-2018 of 30.38\% (BPS, 2018). East Java's cayenne pepper production in 2019 was 536,098 tons which made East Java the largest cayenne pepper producer of all provinces in Indonesia. In contrast, the production of cayenne pepper in Surabaya City is only 691 quintals or $0.013 \%$ of the total cayenne pepper production in East Java Province (BPS, East Java Province in Figures 2020, 2020). Surabaya City has 3,159,481 people (BPS, East Java Province in Figures 2020, 2020). A large number of people will affect the demand for chilli (Dewi, 2009). The high demand for cayenne pepper in Surabaya City is not in line with the chilli production in Surabaya City. To fulfil the order for cayenne pepper, it must be imported from other cities or regencies. This will impact the price of cayenne pepper because Surabaya is close to production centres, so the cost of cayenne pepper is often lower than in cities in other provinces.

The seasonal nature of cayenne pepper causes very high price fluctuations (Farid \& Subekti, 2012). The price fluctuation of cayenne pepper significantly affects inflation (Anwarudin, Sayekti, Marendra, \& Hilman, 2015). High price fluctuations will make it difficult for farmers to make production decisions. High prices for consumers will make it challenging to meet their daily needs (Elvina, Firdaus, \& Fariyanti, 2017). The high fluctuations in the price of cayenne pepper cause the marketing margin to be more significant and the price received by farmers to be lower (Irawan, 2007). Based on this description, it is necessary to conduct a study on price forecasting to reduce the adverse effects of fluctuations felt by farmers and consumers. Therefore, the objectives of this study are: (1) to find out the model for forecasting the price of cayenne pepper in Surabaya City. (2) forecasting the price of cayenne pepper from January 2020 - June 2020 in Surabaya City.

\section{MATERIALS AND METHODS}

The primary method used in this research is the descriptive method. This method aims to obtain a systematic, correct and accurate description of the relationship between facts, characteristics, and phenomena studied (Nazir, 2011). This study uses secondary data. Secondary data is in the form of monthly time series data from July 2010 to December 2019, so there are 114 data. The data is sourced from the Central Statistics Agency (BPS). The price data used is the monthly average price of cayenne pepper at the consumer level in Surabaya City (IDR/Kg). The ARIMA method used to predict the price of cayenne pepper in Surabaya City is the ARIMA method.

The Box-Jenkins methodology, better known as the ARIMA method, is based on the assumption that the time series data is stationary or stationary by differencing one or more times. This method approach is known as the ARIMA model $(p, d, q)$, where $d$ indicates the number of differences carried out until it is stationary. ARIMA ( $p, d, q)$ becomes the ARMA model $(p, q)$. The Autoregressive Integrated Moving Average (ARIMA) model has the following form (Aljandali \& Tatahi, 2018):

$$
Y_{t}=\beta_{0}+\beta_{1} Y_{t-1}+\beta_{2} Y_{t-2}+\ldots .+\beta_{p} Y_{t-p}+C_{1} U_{t-1}+C_{2} U_{t-2}+\ldots+C_{t} U_{t-q}+V_{t}
$$

where $Y t$ is the time data variable to $-t, \beta_{0}+\beta_{1} Y_{t-1}+\beta_{2} Y_{t-2}+\ldots . .+\beta_{p} Y_{t-p}$ is an operator $A R, C_{1} U_{t-1}+$ $\mathrm{C}_{2} \mathrm{U}_{\mathrm{t}-2}+\ldots+\mathrm{C}_{\mathrm{t}} \mathrm{U}_{\mathrm{t}-\mathrm{q}}$ is the MA operator and $\mathrm{v} t$ is the residual value when $t$. 


\section{RESULTS AND DISCUSSION}

The price development of the consumer level of cayenne pepper in Surabaya City is very fluctuating. Fluctuations occur almost every year. Factors causing changes, namely production factors, rain factors, production costs and the length of distribution channels (Indarti, 2015). Data on the price of cayenne pepper at the consumer level in Surabaya City has a random fluctuation pattern. Figure 1 explains that in 2012, the cost of cayenne pepper was still relatively cheaper and relatively stable, with a price range between IDR11,000/Kg - IDR25,000/kg compared to subsequent years. This is due to market demand for basic needs being met because the stock is sufficient, which is that prices tend to fall and are stable (Kominfo Jatim, 2012). After that, from 2013 to 2019, the average cost of cayenne pepper continued to fluctuate annually, but the price of cayenne pepper tended to be higher.

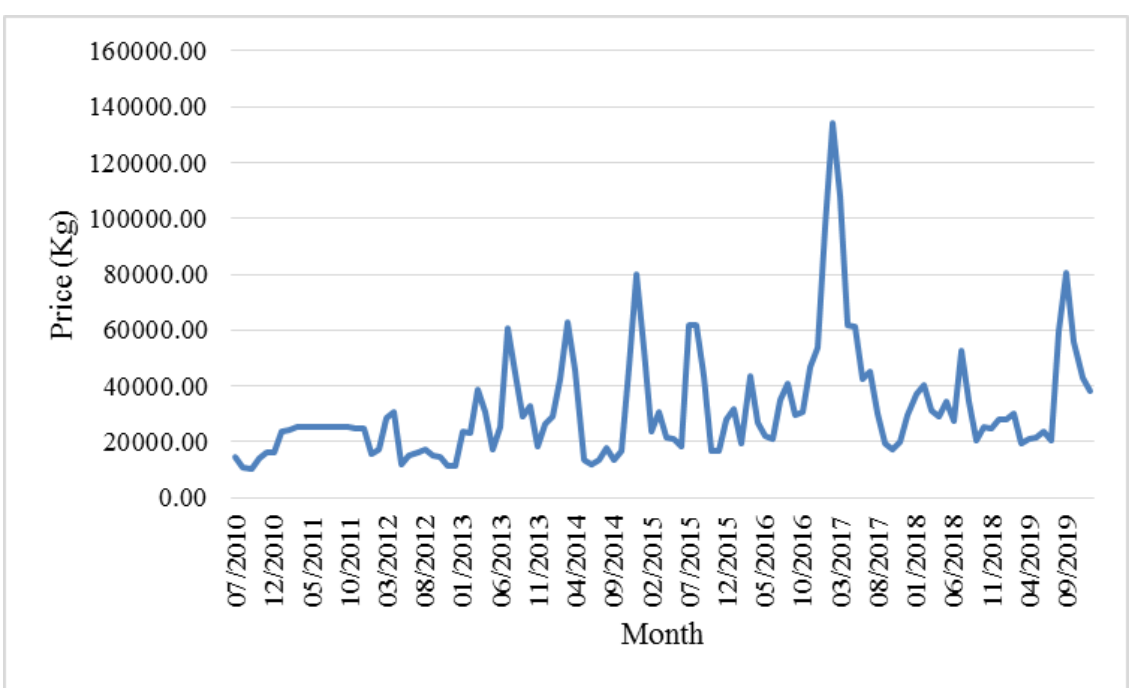

Figure 1. Graph of the consumer-level price of cayenne pepper in Surabaya City. (Source: BPS, 2010-2019)

Based on Figure 1. in mid-2014, the price of chilli experienced a significant decline until it reached a price of IDR11,867/Kg. The cause of falling prices was continued harvests in production centre areas, especially Garut, Cianjur and Magelang areas, so the supply of cayenne pepper in the market became excessive (Utama, 2014). The price of cayenne pepper in Surabaya City experienced a price increase to its highest point in February 2017. In February 2017, the rise in the price of cayenne pepper was caused by the rainy season (Subekti, 2017). Chilli is a commodity with perishable characteristics, so it is very vulnerable during cultivation, harvest, and post-harvest in high rainfall conditions (Subekti, 2017). The price variation of cayenne pepper in Surabaya City from 2018 to mid-2019 is relatively stable.

The average price of cayenne pepper in Surabaya City tends to fluctuate every month. The variation in the price of cayenne pepper in January, February and March is more significant than in other months. In May and June, the cost of cayenne pepper is lower than the additional months because that month is the primary harvest season, so there is an oversupply. According to Hadiana (2011), cit. (Farid \& Subekti, 2012) revealed that chilli planting has two growing seasons (December January) and a short growing season (July - August). The peak harvest season is harvested from April to May, while the low harvest season is from July to August. The consequence of the above cropping season pattern is the potential increase in chilli prices at the end of the year and the beginning of the year due to a shortage of stock in the market. The decline in chilli prices can occur in the middle of the year due to the main harvest. The same opinion was also conveyed by (Anwarudin, Sayekti, Marendra, \& Hilman, 2015), who stated that high price levels generally occur when chilli supplies are scarce, around November - February. The price fluctuations of cayenne pepper occur caused by the increase and decrease in the amount of cayenne pepper supplied by farmers. According to (Prastowo, Yanuarti, \& Depari, 2008), for agricultural commodities, price formation is more influenced by the supply side (supply shock) because the demand side tends to be stable following the development trend.

Forecasting the price of cayenne pepper needs to be analyzed first. The analysis was carried out with a stationary test on the data. ARIMA forecasting requires that the data used must be 
stationary. If the data is already stationary, it is considered to represent the behaviour of the data. Furthermore, after the data has been considered to represent the behaviour of the data, then the A.R. and M.A. values are determined. The AR order in the ARIMA method explains the relationship between the data and the previous period's data. In contrast, the M.A. order explains the relationship between the data and the last residual data. Price data is not determined with a target, so generally, the regression is focused on the relationship with the previous data period (A.R.).

\section{Forecasting the Price of Cayenne Pepper in the Surabaya City Stationarity Test}

The requirement for using the ARIMA method for forecasting is that the data used must be stationary. Determination of stationary data can be done using several ways, one of which is plotting data. The data plot formed can directly show the information is stationary or not. Data is stationary if it is in a specific range of average values. Another way that can be used to find out the stationary information is by using correlograms and unit root tests.

Table 1. Unit-root test results average monthly price of cayenne pepper in Surabaya City at Level

\begin{tabular}{lccc}
\hline \multicolumn{1}{c}{ Description } & Level & t-Statistic & Prob. $^{*}$ \\
\hline Augmented Dickey-Fuller test statistic & & -5.248544 & 0.0000 \\
Test critical values: & $1 \%$ & -3.489659 & \\
& $5 \%$ & -2.887425 & \\
& $10 \%$ & -2.580651 & \\
\hline
\end{tabular}

${ }^{*}$ MacKinnon (1996) one-sided p-values.

Source: Secondary Data Analysis, 2020

Based on the ADF unit root test in table 5.1, it is known that the data is stationary. The absolute ADF t-statistic value indicates this > the critical test value at the alpha level of 1 per cent (0.01), namely $|5,248544|>|3,489659|$. Likewise, the resulting probability has a value of 0.0000 , this value is smaller than 1 per cent alpha $(0.01)$, so it can be concluded that the data is stationary.

\section{Model Identification}

After the data is stationary, the next step is to identify the ARIMA model. The standard method of selecting the ARIMA model using a correlogram is the autocorrelation function (ACF) and the partial autocorrelation function (PACF). The ARIMA model used is ( $p, d, q)$. PACF is used to determine the value of $q, A C F$ is used to determine the value of $p$, and $d$ is the value of the level of differencing.

\begin{tabular}{|c|c|c|c|c|c|c|c|c|}
\hline \multicolumn{2}{|c|}{ Autocorrelation } & \multicolumn{3}{|c|}{ Partial Correlation } & $\mathrm{AC}$ & PAC & Q-Stat & Prob \\
\hline 1 & & 1 & & 1 & 0.697 & 0.697 & 56.842 & 0.000 \\
\hline 1 & $\square$ & 뭉 & 1 & 2 & 0.369 & -0.228 & 72.875 & 0.000 \\
\hline 1 & $\sqsupseteq$ & 1 & 1 & 3 & 0.194 & 0.076 & 77.349 & 0.000 \\
\hline 1 & 口 & 1 & 1 & 4 & 0.140 & 0.053 & 79.711 & 0.000 \\
\hline 1 & 1 & I & 1 & 5 & 0.067 & -0.102 & 80.252 & 0.000 \\
\hline 1 & י & 1 & ال & 6 & 0.066 & 0.136 & 80.793 & 0.000 \\
\hline 1 & 19 & 1 & 1 & 7 & 0.075 & -0.027 & 81.493 & 0.000 \\
\hline 1 & ין & 1 & 1 & 8 & 0.089 & 0.044 & 82.489 & 0.000 \\
\hline 1 & 1 & I & 1 & 9 & 0.025 & -0.110 & 82.570 & 0.000 \\
\hline 1 & 1 & 10 & 1 & 10 & -0.038 & -0.026 & 82.754 & 0.000 \\
\hline 1 & 1 & 1 & طا马 & 11 & -0.001 & 0.145 & 82.754 & 0.000 \\
\hline 1 & 1 & 1 & 1 & 12 & 0.059 & -0.017 & 83.203 & 0.000 \\
\hline 1 & 1 & 맘 & 1 & 13 & 0.006 & -0.123 & 83.208 & 0.000 \\
\hline 1 & 1 & 1 & 1 & 14 & -0.057 & -0.001 & 83.641 & 0.000 \\
\hline 1 & 1 & 1 & $\square$ & 15 & 0.020 & 0.187 & 83.694 & 0.000 \\
\hline 1 & 口 & 1 & $\square$ & 16 & 0.170 & 0.156 & 87.603 & 0.000 \\
\hline 1 & $\sqsupseteq$ & 1 & 1 & 17 & 0.231 & 0.005 & 94.897 & 0.000 \\
\hline 1 & 口 & 1 & 1 & 18 & 0.187 & -0.050 & 99.720 & 0.000 \\
\hline 1 & יا & 1 & 1 & 19 & 0.135 & -0.005 & 102.27 & 0.000 \\
\hline 1 & ים & 1 & ו & 20 & 0.121 & 0.062 & 104.33 & 0.000 \\
\hline
\end{tabular}

Figure 2. ACF and PACF average monthly price of cayenne pepper in Surabaya City July 2010December 2019 at Level Level. (Source: Secondary Data Analysis, 2020) 
Based on Figure 2. the correlogram of the average monthly price of cayenne pepper in Surabaya City shows a drastic decrease (cut off) after the second leg in ACF and PACF. Therefore, based on Table 2, ARIMA's tentative model for the average monthly price of cayenne pepper in Surabaya City is:

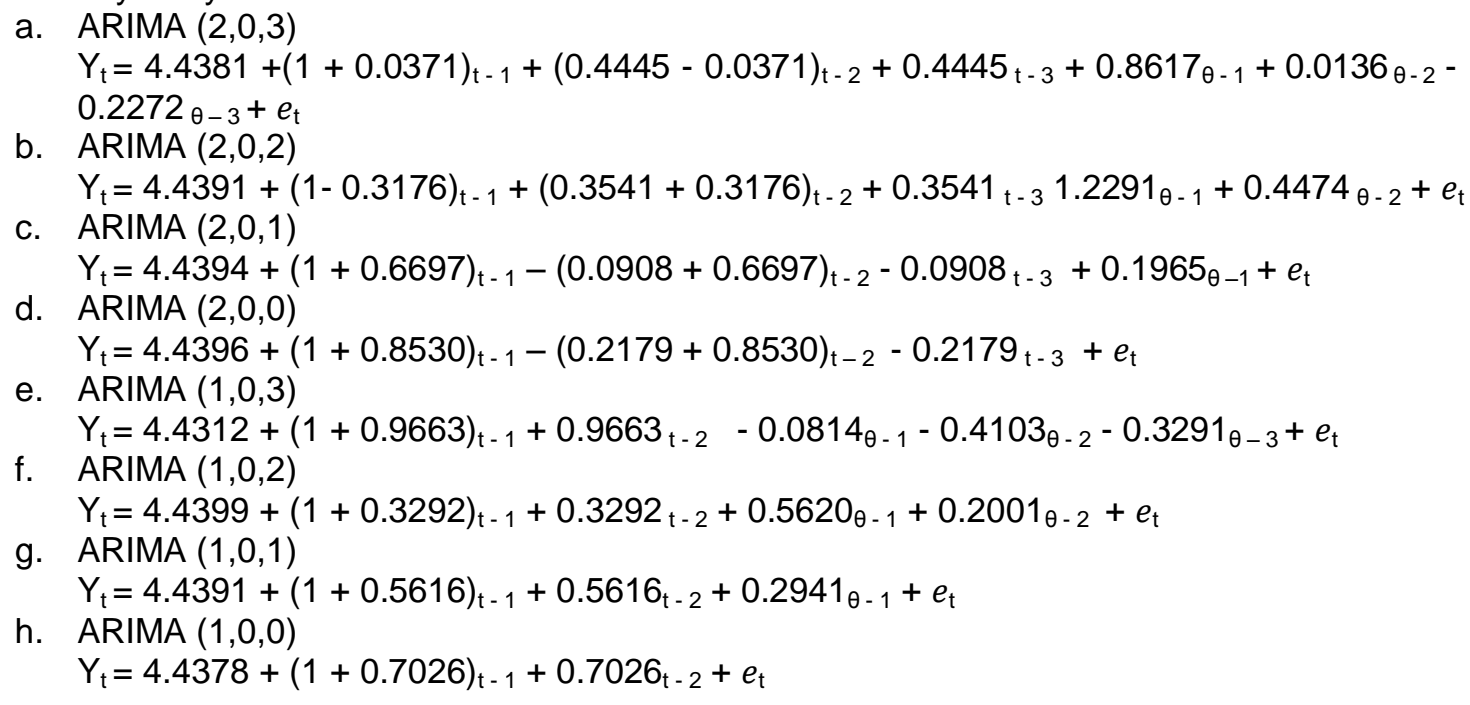

\section{Model Estimation}

After getting the tentative ARIMA model, the next step is to estimate the tentative model. At the estimation stage, the feasibility test of the model is carried out by looking for the best model. The best model is based on goodness of fit, namely the level of significance of the independent variables, including constants that pass the t-test, $F$ test, and the coefficient of determination (R2). Table 2 shows the results of the initial model estimation of pepper prices in Surabaya.

Table 2. ARIMA model estimation of cayenne chili prices in the Surabaya City

\begin{tabular}{cccccc}
\hline Model & $\mathrm{R}^{2}$ & $\mathrm{~F}$ & $\mathrm{~F} \mathrm{sig}$ & $\mathrm{AIC}$ & \multicolumn{1}{c}{ SIC } \\
\hline $2,0,3$ & 0.5389 & 20.8433 & 0.0000 & -0.78211 & -0.6141 \\
$2,0,2$ & 0.5355 & 24.9061 & 0.0000 & -0.79271 & -0.64869 \\
$2,0,1$ & 0.5199 & 29.5108 & 0.0000 & -0.77883 & -0.65883 \\
$2,0,0$ & 0.5179 & 39.3951 & 0.0000 & -0.79236 & -0.69635 \\
$1,0,3$ & 0.5310 & 24.4506 & 0.0000 & -0.78245 & -0.63844 \\
$1,0,2$ & 0.5223 & 29.7919 & 0.0000 & -0.78345 & -0.66344 \\
$1,0,1$ & 0.5191 & 39.5828 & 0.0000 & -0.79479 & -0.69879 \\
$1,0,0$ & 0.4940 & 54.1785 & 0.0000 & -0.7622 & -0.69019 \\
\hline
\end{tabular}

Source: Secondary Data Analysis, 2020

Based on the goodness of fit in Table 2, three ARIMA models can be selected, namely the ARIMA $(2,0,0)$, ARIMA $(1,0,1)$ and ARIMA $(1,0,0)$ models. The AIC and SIC values of the ARIMA model $(1,0,1)$ also have the smallest values compared to the importance of other models. Based on the value of the coefficient of determination (R2) and the value of $F$, the ARIMA model $(1,0,1)$ is better. The ARIMA model $(1,0,1)$ has an R-squared value of 0,5191 which means that the independent variables can explain $51,91 \%$ of the variation of the dependent variable.

\section{Model Diagnostic Test}

In the identification step, the best model has been obtained, namely ARIMA $(1,0,1)$ for the price of cayenne pepper. The next step is to perform a diagnostic test on the model. The model is good if it has a relatively small residual value because the residual is random (white noise).

The ARIMA model $(1,0,1)$ has ACF and PACF values, as shown in Figure 3. The Ljung-Box statistic value up to lag 20 is 20,468 . The statistical significance of $X^{2}$ with a df of 20 at the alpha level of 1 per cent is 37.57. The Ljung-Box value is smaller than the $X^{2}$ statistic value, indicating that the residual is relatively small, so the residual is random. Based on this analysis, it can be concluded that this model can predict the price of cayenne pepper in the next period. 


\begin{tabular}{|c|c|c|c|c|c|c|}
\hline Autocorrelation & Partial Correlation & & $\mathrm{AC}$ & PAC & Q-Stat & Prob \\
\hline 1 | & 1 & 1 & 0.012 & 0.012 & 0.0164 & \\
\hline 11 & 11 & 2 & -0.013 & -0.014 & 0.0377 & \\
\hline I 1 & Iप 1 & 3 & -0.090 & -0.090 & 1.0021 & 0.317 \\
\hline ין 1 & ים 1 & 4 & 0.128 & 0.131 & 2.9762 & 0.226 \\
\hline 1 & 1 & 5 & -0.092 & -0.101 & 4.0064 & 0.261 \\
\hline 171 & 171 & 6 & 0.045 & 0.047 & 4.2513 & 0.373 \\
\hline 11 & \begin{tabular}{l|l}
1 & 1
\end{tabular} & 7 & -0.023 & -0.006 & 4.3170 & 0.505 \\
\hline ים ו & ים ו & 8 & 0.119 & 0.091 & 6.0939 & 0.413 \\
\hline \begin{tabular}{l|l}
1 & 1
\end{tabular} & 10 & 9 & 0.008 & 0.034 & 6.1021 & 0.528 \\
\hline 吗 1 & 吅 1 & 10 & -0.121 & -0.148 & 7.9695 & 0.436 \\
\hline 1 & 17 & 11 & -0.032 & 0.011 & 8.0987 & 0.524 \\
\hline ים & ין ו & 12 & 0.146 & 0.120 & 10.851 & 0.369 \\
\hline$1 \longdiv { 1 }$ & $1[1$ & 13 & 0.019 & 0.002 & 10.896 & 0.452 \\
\hline 도 & 吅 & 14 & -0.162 & -0.147 & 14.363 & 0.278 \\
\hline 101 & 101 & 15 & -0.062 & -0.055 & 14.872 & 0.315 \\
\hline ים ו & ים ا & 16 & 0.128 & 0.120 & 17.090 & 0.251 \\
\hline ים & ין & 17 & 0.151 & 0.152 & 20.199 & 0.164 \\
\hline $1 \sqrt{1}$ & 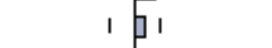 & 18 & 0.040 & 0.071 & 20.425 & 0.202 \\
\hline 11 & 11 & 19 & -0.010 & -0.015 & 20.439 & 0.252 \\
\hline 111 & 101 & 20 & 0.014 & -0.030 & 20.468 & 0.307 \\
\hline
\end{tabular}

Figure 3. Residual ACF and PACF values from the ARIMA model $(1,0,1)$ the monthly price of cayenne pepper in the Surabaya City (Source: Secondary Data Analysis, 2020)

The ARIMA model is good if it has a small MAPE value. The smaller the MAPE value, the forecasting results are closer to the actual value.

Table 3. Mean Absolute Percentage Error Value of Selected ARIMA Model

\begin{tabular}{cc}
\hline Model & MAPE $(\%)$ \\
\hline ARIMA $(1,0,1)$ & 3,84 \\
\hline Source: Secondary data analysis, 2020 &
\end{tabular}

Based on Table 3. ARIMA model $(1,0,1)$ has a MAPE value of 3.84 per cent. The MAPE value shows the average absolute error of the forecast compared to the actual value of 3.84 per cent. The MAPE value is obtained using the fundamental error in each period divided by the real observed value for that period. Then, the absolute percentage error is averaged. The function of MAPE is to measure the accuracy of the forecasting method in forecasting the tested data. So the smaller the MAPE value, the better the forecasting results will be. ARIMA general equation model $(1,0,1)$ for forecasting the price of cayenne pepper at the consumer level in Surabaya:

$Y_{\mathrm{t}}=4.4391+(1+0.5616)_{\mathrm{t}-1}+0.5616_{\mathrm{t}-2}+0.2941_{\theta-1}+e_{\mathrm{t}}$
or
$\mathrm{Y}_{\mathrm{t}}=4.4391+1.5616_{\mathrm{t}-1}+0.5616_{\mathrm{t}-2}+0.2941_{\theta-1}+e_{\mathrm{t}}$

\section{Cayenne Pepper Price Forecast}

The best ARIMA model obtained through the previous steps is ARIMA $(1,0,1)$, both for the price of cayenne pepper. The ARIMA model $(1,0,1)$ produces predictions with a period that is not too far away. The predictive value of cayenne pepper in Surabaya City is influenced by the price one month ago. The significant variable in ARIMA $(1,0,1)$ indicates that the predictive factor for the price of cayenne pepper in Surabaya City is one month earlier.

Table 4. Results of forecasting consumer-level cayenne pepper prices in Surabaya City in January 2020 - June 2020

\begin{tabular}{ccc}
\hline Year & Months & Cayenne Pepper $(\mathrm{Rp} / \mathrm{Kg})$ \\
\hline 2020 & Januari & 33,646 \\
& Februari & 30,790 \\
& Maret & 29,294 \\
\hline
\end{tabular}


Table 4. Results of forecasting consumer-level cayenne pepper prices in Surabaya City in January 2020 - June 2020

\begin{tabular}{ccc}
\hline Year & Months & Cayenne Pepper $(\mathrm{Rp} / \mathrm{Kg})$ \\
\hline & April & 28,486 \\
& Mei & 28,042 \\
& Juni & 27,796 \\
\hline
\end{tabular}

Source: Secondary Data Analysis, 2020

The monthly price forecast for cayenne pepper is carried out for the next six month period, January 2020-June 2020. This period was chosen because the ARIMA forecasting method is suitable for forecasting highly volatile data. Forecasting results as in Table 4 show a pattern of price changes in the 2020 timeframe, as in previous years, the way of changes in the price of cayenne pepper is random. Following the basic principle, forecasting accuracy is perfect for short-term forecasting, while forecasting accuracy is not suitable for long-term forecasting. Long-term forecasting using the ARIMA method usually produces forecasts that tend to be flat (flat/constant). One of the advantages of the ARIMA model is that it ignores the independent variables completely in making forecasts. ARIMA uses past and presents dependent variables to produce accurate short-term forecasts. The ARIMA method is suitable if observations from time series are statistically related (conditional) (Hanke, Reitsch, \& Wichen, 1999). The same opinion was conveyed by (Ma, Hu, Lin, \& Yanben, 2018), who stated that the ARIMA model is a method that can explain dynamic data changes and can be used to perform statistical analysis at specific periods and conditions. In particular, this model is suitable for short-term predictions.

Large deviations occur when the forecast period is too long. The forecasting results in this study are based on historical data on consumer-level prices of cayenne pepper. The ceteris paribus assumption applies, where the factors that cause price fluctuations and government policies are considered constant and will not change in the future. The research results (Dwiputri, Kusufi, \& Allo, 2019) used the ceteris paribus assumption using univariate forecasting methods, meaning that forecasting did not involve intervention/conditional intervention changes in other economic variables. D.I. GDP prediction results. Using the ARIMA method, Yogyakarta applies ceteris paribus, namely DIY policy and economic conditions that are constant as in previous years and do not involve changes in other variables that affect the future (Regional Statistics Center, 2017).

Forecasting results show that the price of cayenne pepper has decreased in the period January 2020 to June 2020. In January, the cost of cayenne pepper was IDR33,646 and gradually reduced in the following months. The highest price of cayenne pepper occurred at the beginning of the year. The lack of market supply influenced the situation. The cause of the shortage of chilli stocks in the market arises because at the beginning of the year is the peak of the rainy season, so the harvest produced is small, and the distribution of chillies from farmers to the market is hampered. The height of the rainy season encourages the emergence of various chilli diseases that increase the risk of crop failure. As a result, during the harvest season in December, there was a shortage of chilli production supply (Rachmad, Setiowati, \& Wiyatno, 2011).

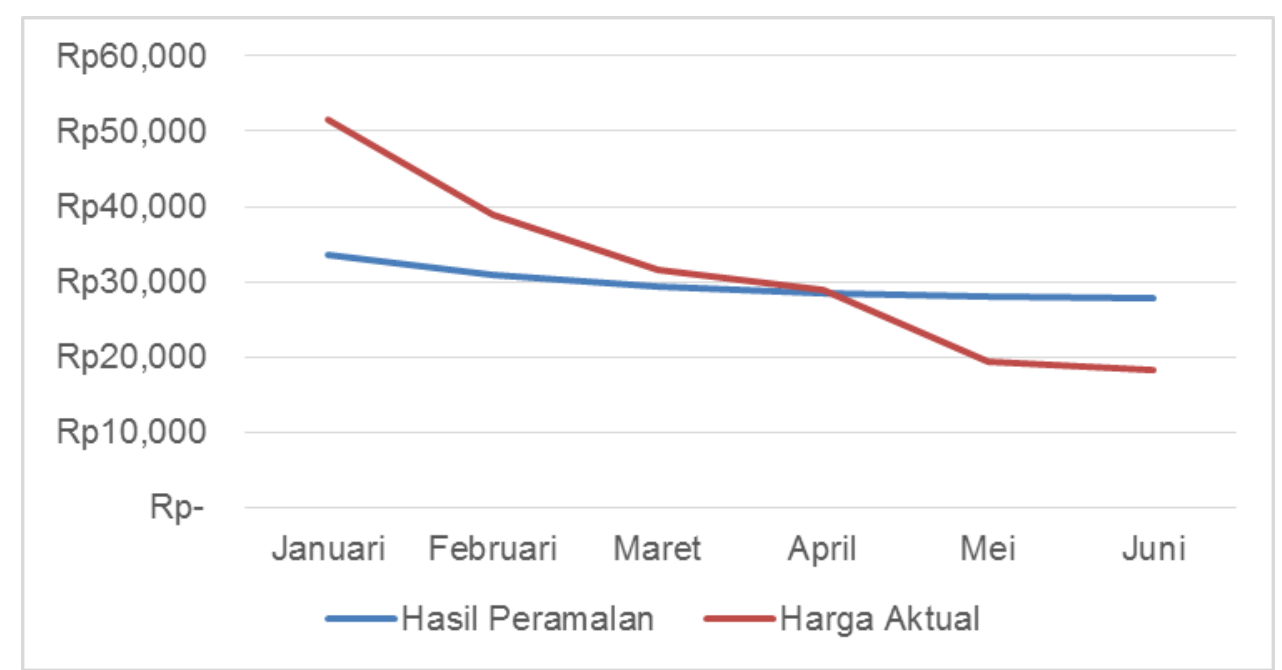

Figure 5. Graph of comparison of actual monthly prices and predicted monthly fees of cayenne pepper in the Surabaya City (Source: Secondary Data Analysis, 2020) 
The results of the prediction of the price of cayenne pepper in the January - June 2020 period relatively follow the price pattern in the previous year, which is a random pattern. The level of fluctuation in the price of cayenne pepper is also somewhat the same as the last year, but in 2020 the price of chilli fell quite deeply in May 2020. This may be due to an unexpected factor, namely the Covid-19 pandemic. According to Abdul Hamid (Jannah, 2020), the low price of chilli is caused by some local governments' implementation of Large-Scale Social Restrictions (PSBB) to prevent the broader spread of the COVID-19 virus. Chilli farmers are harvesting, so chilli distributors from farmers to markets in various regions are limited, and the market does not absorb the chilli harvest. The impact of the PSBB has also reduced the demand for chilli from restaurants and places to eat.

Forecasting the price of cayenne pepper can be considered by the Directorate General of Horticulture in making recommendations for planting patterns and areas and early warnings in the form of Early Warning System (EWS) data that is sent to all regions every month. The purpose of EWS is to prevent oversupply (Fajar, 2020). This program has been carried out for several years but has not been running effectively, so that chilli prices always fall almost every year due to the abundance of production. The policy plan requires coordination and synchronization between the Provincial Agriculture Service and the District Agriculture Office for chilli centres to determine the planned planting area based on each district's percentage and production quota to sub-district. It is also necessary to increase cooperation between regencies and production centres in terms of market information networks, production, planting area, and use of technology. The socialization of the regulation of planting patterns and regions needs to be carried out more intensively and continuously to chilli farmers in production centres so that farmers do not experience losses due to the abundance of chilli production. Socialization of the regulation of planting patterns and areas can be in the form of recommendations for polyculture cultivation or the cultivation of commodities other than chilli that are profitable when there is a decline in prices.

Government policy in handling low chilli prices occurs by absorbing chilli from farmers through the Indonesian Farmers Center (TTIC) Shop with higher prices. The procedure accommodated by the Ministry of Agriculture was followed by chilli industry players and several other parties. Chilli industry players through Gapoktan are committed to making purchases. The chilli industry players include P.T. Wings Food, P.T. Mineral Food Barn, and P.T. Bumi Tirta Margo, Surabaya. Perum Bulog Bojonegoro is also committed to buying and securing chilli prices for farmers (Ministry of Agriculture of the Republic of Indonesia, 2019). The government's steps in establishing partnerships with chilli industry players need to be developed, not only when chillies experience oversupply and plummeting prices. A reliable and sustainable partnership institution needs to be created by the government so that chilli agribusiness development can handle price fluctuations. According to (Saptana, et al., 2005), partnerships between farmers and companies can increase efficiency, productivity, and economic value.

Other efforts made by the government to suppress falling prices include socializing the sales delay system to the Agricultural Service Officers and Chili Champion Farmers in all central areas and providing cool storage rental facilities in several places that farmers can use to store farmers crops (Fajar, 2020). The development of large capacity cold storage (cooling warehouses) in several chilli production centres is needed. Chilli can be stored first in cold storage when chilli production is abundant, and the price falls until prices improve. According to (Asgar, 2009) storage of fresh chillies in a cold room at $40 \mathrm{C}$ can suppress the rate of development of microorganisms and biochemical changes.

Post-harvest technology for chilli to produce dried chilli and socializing the use of dried chilli for household needs. Most chilli consumers now want chilli in fresh form and very rarely use dry chilli, even though dry chilli is quite a lot in several neighbouring countries. Besides being consumed fresh, chilli can be processed into several processed forms such as sauce, chilli sauce, paste, powder, and anaesthetic drugs (Hartuti \& Asgar., 1994). Post-harvest processing can absorb excess stock in the market and keep the price of cayenne pepper stable.

The government also needs to determine a reasonable base price for chilli, which does not harm farmers, does not burden consumers, benefits traders, and has a good impact on society and the country's economy. The determination of this introductory price must consider the national chilli break-even point (BEP). Many of the policies taken by stakeholders when chilli prices are low are repressive and short-term. The possibility of these problems occurring in the future is relatively high and is very likely to happen again. 


\section{CONCLUSIONS AND SUGGESTIONS}

Based on the research results that have been done, it can be concluded that the best model used for forecasting the price of cayenne pepper in Surabaya is ARIMA $(1,0,1)$, with a MAPE value of 3.84 per cent. The results of forecasting the cost of cayenne pepper in the period January 2020 June 2020 in Surabaya City decreased. Forecasting the price of cayenne pepper using the ARIMA method has a reasonably high accuracy for short-term forecasting. Commodities that have very volatile prices can be seen from the minimal MAPE value. Hence, it is very likely to be used as consideration in making recommendations for pattern and planting areas by the Director-General of Horticulture through the Early Warning System (EWS) program or policies related to handling chilli prices. Approaches that can be taken to prevent price declines that harm farmers are establishing partnerships with chilli industry players, cold storage development, use of post-harvest technology for chilli, dissemination of polyculture cultivation or other commodities, and the determination of the introductory price of chilli set by the government.

\section{REFERENCES}

Aljandali, A., \& Tatahi, M. 2018. Economic and Financial Modelling with Eviews. Cham: Springer International Publishing AG.

Anwarudin, M. J., Sayekti, A. L., Marendra, A., \& Hilman, Y. 2015. Dinamika produksi dan volatilitas harga cabai: antisipasi strategi dan kebijakan pengembangan. Pengembangan Inovasi Pertanian 8 (1), 33-42.

Asgar, A. 2009. Penanganan Pascapanen Beberapa Jenis Sayuran. Lembang: Balai Penelitian Tanaman Sayuran.

Balai Statistik Daerah. 2017. Analisis Makro Ekonomi Daerah Istimewa Yogyakarta. Yogyakarta: Badan Perencanaan Pembangunan Daerah Daerah Istimewa Yogyakarta.

BPS. 2020. Hortikultura. Retrieved from BPS.

BPS. 2020. Provinsi Jawa Timur dalam Angka 2020. Surabaya: Badan Pusat Statistik Jawa Timur.

Dewi, T. R. 2009. Analisis permintaan cabai merah (Capsicum annum L) di Kota Surakarta. Surakarta: UNS.

Dwiputri, I. N., M.S. Kusufi, \& A.G. Allo. 2019. Projections of regional macroeconomic conditions using the univariate forecasting method. Economics Development Analysis Journal 8(3), 329342.

Elvina, M. Firdaus, \& A. Fariyanti. 2017. Transmisi harga dan sequentil bargaining game perilaku pasar antar lembaga pemasaran cabe merah di Indonesia. Jurnal Agribisnis Indonesia 5(2), 89-110.

Fajar, T. 2020. Harga Cabai Anjlok Akibat Kebijakan PSBB, Petani Jadi Merugi. Retrieved from OkeFinance: https://economy.okezone.com/read/2020/05/12/320/2212750/harga-cabaianjlok-akibat-kebijakan-psbb-petani-jadi-merugi?page $=2$

Farid, M., \& A. N. Subekti. 2012. Tinjauan terhadap produksi, konsumsi, distribus dan dinamika harga cabe di Indonesia. Buletin Ilmiah Litbang Perdagangan 6 (2), 211-233.

Hanke, J., A.G. Reitsch, \& D. Wichen. 1999. Peramalan Bisnis. Edisi Ketiga. Jakarta: PT Prenhallindo.

Hartuti, N., \& A. Asgar. 1994. Kualitas bahan baku dan hasil olahan cabai di tingkat industri komersial dan rumah tangga di Bandung. Buletin Penelitian Hortikultura 26 (2), 96-103.

Indarti, D. 2015. Outlook Cabai. Jakarta: Pusat Data dan Sistem Informasi Pertanian.

Irawan, B. 2007. Fluktuasi harga, transmisi harga dan marjin pemsaran sayuran dan buah. Analisis Kebijakan Pertanian 5 (4), 358-373.

Jannah, M. S. 2020. Harga Cabai ANjlok, Nasib Petani di Ujung Tanduk. Retrieved from Tirto.id: https://tirto.id/harga-cabai-anjlok-nasib-petani-di-ujung-tanduk-flwd

Kementerian Pertanian Republik Indonesia. 2019. Harga Cabai JAtuh, Kementan Gerak Cepat Bantu Petani Tuban. Retrieved from Kementerian Pertanian Republik Indonesia: https://www.pertanian.go.id/home/?show=news\&act=view\&id=3732

Kominfo Jatim. 2012. Harga Cabe Rawit Turun. Surabaya: Dinas Komunikasi dan Informatika Provinsi Jawa Timur.

Lihua M., Hu, C., Lin, R., and Yanben, H. 2018. Arima model forecast based on Eviews software. IOP Conf. Series: Earth and Environmental Science.

Nazir, M. 2011. Metode Penelitian. Bogor: Penerbit Ghalia Indonesia.

Prakoso, D. W. 2018. Analisis peramalan harga bawang merah di Kota Medan dan faktor-faktor yang mempengaruhinya. Medan: Skripsi. Universitas Sumatera Utara. 
Prastowo, N. J., Yanuarti, T., \& Depari, Y. 2008. Pengaruh distribusi dalam pembentukan harga komoditas dan impikasinya terhadap inflasi. Bank Indonesia.

Pratiwi, L., \& A.H. Al Rosyid. 2020. Forecasting of chilli prices in the special region of Yogyakarta, Indonesia based on Harga Pangan applications (Arima approach). Proceeding International Conference on Green Agro-Industry 4, 39-47.

Rachmad, S., R. Setiowati, \& D. Wiyatno. 2011. Ketersediaan, konsumsi dan inflasi cabai di Kabupaten Tuban. Bunga Rampai Statistik Percabaian.

Saptana, E. K., Indrianingsih, Ashari, S. Friyanto, Sunarsih, \& V. Daris. 2005. Pengembangan Model Kelembagaan Kemitraan Usaha yang Berdaya Saing di Kawasan Sentra Produksi Hortikultura. Bogor: Pusat Penelitian dan Pengembangan Sosial Ekonomi Pertanian.

Subekti, N. A. 2017. Inflasi. Analisis Perkembangan Harga Bahan Pangan Pokok di Pasar Domestik dan Internasional.

Utama, R. 2014. Cabe. Analisis Monitoring Perkembangan Harga. 